\title{
Restructuring the Defence Industry and Arms Production in Russia
}

\author{
ANTONIO SÁNCHEZ-ANDRÉS
}

AT THE BEGINNING OF 1997, after five years of failed reforms in the defence industry, there took place a substantial change in the administrative structure running this sector. The Ministry of Economic Affairs took over the restructuring of the defence industry and thereby defined a new way of tackling reforms in this industrial sector. Three elements stand out in the new approach: intersectorality, a predominance of civilian elements and a greater realism. This approach, therefore, represents a break with the idea in force up to that moment of the best way to tackle problems related to the defence industry, which was greatly conditioned by its Soviet heritage. Although two years later this new way of approaching the restructuring of the defence industry has come under question, it can be claimed that some of the changes introduced will condition the future industrial policy implemented in this sector.

This article aims to do two things: firstly, to highlight whether relevant decisions have been made in the restructuring of this sector during the time it has been under the control of the Ministry of Economic Affairs and secondly, to point out the restructuring tendencies once the main objective of this industry, specifically the supply of weapons, had been achieved. This article will concentrate only on those aspects related to domestic weapons demand, this being the element that gives meaning to the defence industry in itself. In the first place, the situation inherited by the Ministry of Economic Affairs will be set out, as will, in connection with this, the aims of the restructuring programme. In the second place, the changes which took place in the sector as a whole will be examined, focusing on considerations of its size as well as on reforms introduced in the methods of internal reorganisation. Thirdly, some limits which are relevant to the industrial policy adopted will be pointed out. The analysis of these issues will be carried out in the light of the de facto priorities of weapons production, in such a way that it will end by underlining the relationship between the model of the future Russian defence industry and the production of weapons necessary to meet the domestic requirements.

The restructuring of the defence industry

Reform precedents

During the Soviet period the administrative structure of the defence industry had enjoyed some very important privileges, but in 1992 it became a mere section of the 
Ministry of Industry. From this moment onwards it gradually rose in standing (Rossiiskii, and then Gosudarstvennyi komitet oboronnoi promyshlennosti-GKOP) until it reached ministry level (Minoboronprom) in May 1996. Nevertheless, in March 1997 this tendency was reversed when Minoboronprom was wound up and part of it absorbed by the Ministry of Economic Affairs.

The first five years of the transition saw a continuity in the approach to the reforming and restructuring of the defence industry, although mediated by the capacity for action of the administrative body which was running it. Among the most important initiatives in the restructuring and adapting of the industry to the new necessities of arms production are the reduction in the number of organisations linked to the sector, changes in ownership, and the creation of new organising methods, especially associations, as well as changes in the statute of state-owned companies.

As regards the reduction in size of the defence industry, the separation of companies from the sector has been quite limited in spite of the important privatisation process that took place. The state has continued to play a particularly important role in the privatised organisations and, as for the state-owned companies, they have accepted the drop in their number with great reluctance. Sources close to the GKOP/Minoboronprom estimated that, at the beginning of 1996, there were 525 companies that should not be privatised, and yet, halfway through that year, an official list of 480 defence organisations which were not suitable for privatisation was approved. ${ }^{1}$ However, in the middle of 1997 the number of state-owned defence companies still ran to 738 (see Table 1) and the selling of shares of many organisations had been paralysed. This means that a more thorough process of substantial privatisation was needed in the sector. ${ }^{2}$ This situation becomes more serious if we consider that the state, through the GKOP/Minoboronprom, did not achieve effective control over state-owned companies and state ownership in privatised organisations, ${ }^{3}$ which questions the effectiveness of the restructuring policy.

Another line of restructuring followed by the GKOP/Minoboronprom was the consolidation of the state-owned organisations by means of a special status: kazennye predpriyatiya (treasury factories, i.e. fully state-owned companies). This refers to those companies where the state is entitled to determine their production activity, at the same time as being ultimately responsible for their financial obligations. ${ }^{4}$ Nevertheless, despite the raising of the hierarchical level of the administrative structure of the defence industry, the creation of this type of company has been merely anecdotal. To give a concrete example, at the beginning of 1997 only five full state-owned companies had been set up, in spite of an intention to create 45 such organisations in 1996 and to go on progressively to form some $370 .^{5}$ On the other hand, as regards the setting-up of state-owned organisational structures whose nucleus was made up of a research centre, two types were distinguished; the state scientific centres (Gosudarstvennyi nauchnyi tsentr-GNTs) which carry out research tasks and the federal scientific-production centres (Federal'nyi nauchnyi proizvodstvennyi tsentr-FNPTs) where research, design and production activities (short series) ${ }^{6}$ will be conducted. However, up to the beginning of 1997, a total of 17 state scientific centres and six federal scientific-production centres had been created, as the process had been paralysed almost since the very setting up of Minoboronprom.

As to the creation of associations, ${ }^{8}$ their setting-up was promoted although there 
was uncertainty over which legal format to adopt. Many of these associations intended once again to set up the traditional relationships maintained during the Soviet period but without any visible priority on the part of the state in this process. Therefore, quite a few associations appeared but, in the midst of an economic crisis and a drop in military orders, their existence was rather formal, with a marked internal instability. To illustrate this, it can be pointed out that up to April 199762 financial-industrial groups (one of the different types of association) had been created and legally acknowledged ${ }^{9}$ and in 23 of these there was some participation by defence organisations. However, in only 10 was the number of these organisations significant enough to define the group profile by its arms production.

Yet the allocation of orders and the restructuring in the defence industry have been badly coordinated. On the one hand, a reduction in military orders should be reflected in a very significant concentration in their distribution. Although in 1997 half the budget for military orders was concentrated in some 50 organisations, the other half was distributed among some 1200 groups, thereby spreading a substantial part of the budget among defence organisations with a somewhat dubious claim to arms production and a questionable capacity to fulfil such orders. This is to say that both the restructuring within the sector and the policy introduced to encourage changes have been residual despite the sharp fall in military orders and the admission that these orders would not rise in the future. On the other hand, this is made even more serious if we take into account payment for military orders. Between 1994 and 1997 the debts accumulated by the state for military orders rose to 16.5 billion rubles, a figure equivalent to the volume of orders intended to be placed in 1998 (15.3 billion rubles)..$^{10}$ This means that the irreversible drop in the volume of military orders has not only not prompted the restructuring of the defence industry but has also introduced additional problems related to the rise in non-payment for these orders by the state. Therefore, the appearance of Minoboronprom has neither contributed to a rationalisation in military orders nor proved to be any incentive for the defence industry to adapt itself to the new situation in the country.

At the beginning of 1997 the restructuring in the Russian defence industry was at a standstill. One of the main reasons for this failure was the maintenance of an administrative structure and an approach which were very sectionalised and very sensitive to the interests of traditional pressure groups existing in this industry, in such a way as to reproduce the Soviet status quo although in a different institutional context. The disappearance of Minoboronprom and its partial absorption by the Ministry of Economic Affairs opened up a new era in the restructuring of the defence industry which allowed a different perspective on the task to be taken.

\section{The aims of the new restructuring}

The new defence industry restructuring programme was based on the 'Conception of the reform of the defence industry', ${ }^{11}$ starting from which a specific restructuring programme for this industrial sector would be worked out and a group of decrees or legal provisions necessary to express it in concrete terms approved. From 1998 to 2000 the necessary changes related to the restructuring in the defence industry would be put into practice, in particular the essential legal bases would be approved by the 
TABLE 1

Size Objectives in the Restructuring of the Defence Industry

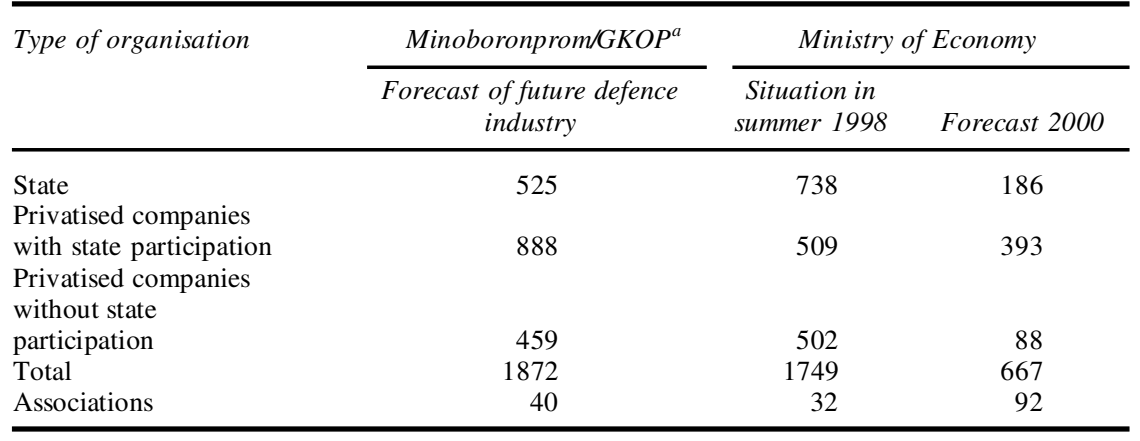

${ }^{\mathrm{a}}$ This is a reform project put forward by sources close to the GKOP and therefore to Minoboronprom in 1996. Among the state-owned organisations are included 367 fully state-owned companies (kazennye predpriyatiya), 58 unitary companies (unitarnye predpriyatiya), 40 state scientific centres (Gosudarstvennye nauchnye tsentry-GNTs) and 60 federal scientific-production centres (Federal'nye nauchnye proizvodstvennye tsentry-FNPTs).

Sources: I. Labrushenkova, \& A. Voyakina, 'Institutsional'nye preobrazovaniya v oboronnom komplekse', Voprosy ekonomiki i konversii, 1996, 1, p. 55; NITs PEU, 'Deistvuyushchaya struktura oboronno-promyshlennogokompleksa Rossii'. http://www.vpk.ru:8082/www-vpk/vpk/vit/stat4.htm, January 1998; and Ekspert, 1998, 6, p. 51.

beginning of 1998. The basic aim of the planned restructuring was fulfilment of the long-term state arms programme, 1996-2005, which aimed to cover the country's arms requirements. ${ }^{12}$

One prime characteristic of the new period of reforms in the defence industry which is worth underlining is that the official body in charge of the restructuring would no longer be Minoboronprom or any other sectoral body closely linked to the defence sector, but the Ministry of Economic Affairs. Therefore, the application of a new approach with respect to the reform in this industry was foreseeable. This was characterised, firstly, by its emphasis on more intersectoral aspects and, secondly, by its tackling of the problems from a more civilian perspective while still acknowledging the strategic peculiarities of the defence sector. ${ }^{13}$

The restructuring policy takes into account not only the worsening of the defence industry's economic situation in 1997 but also the weakening of the armed forces, the drop in the state's military orders, as well as the trend (decline tending towards stabilisation) of the Russian economy in general. ${ }^{14}$ Consistent with these characteristics, the restructuring programme decided on a significant reduction in the size of the defence industry, as well as a physical change (an increase in the types of ownership and methods of organisation in the sector). ${ }^{15}$ Therefore, in the year 2000, the defence sector would be made up of 667 organisations and the number of associations (integrated structures) would noticeably increase, which is to say that the defence sector would experience a significant reduction in the number of organisations. The new defence sector will focus on fulfilling a few priorities in high-tech arms production in such a way as to be a support to the scientific centres in particular, so as to avoid their permanent deterioration. ${ }^{16}$

This restructuring would appear to be guided by several general criteria. The first 
is rationalisation of the management and allocation of military orders. To achieve this, the intention would be to concentrate the military orders in a reduced number of defence organisations whose production would, essentially, be military. As a result, a significant number of organisations would be left without military orders and therefore would be excluded from the sector, a phenomenon that would lead to a substantial decrease in the size of the defence industry. ${ }^{17}$ This change in the managing of military orders would mean the creation of a defence industry nucleus which would be limited to activities related to arms production and national security. This nucleus should be state-owned. One specific example would be that, after the restructuring, of the 2000 firms that traditionally received military orders and gave employment to some 2.5 million workers, only some 300 organisations and some 900000 workers would be responsible for state orders. ${ }^{18}$ On the other hand, it was assumed that coherence between the management of orders and the restructuring in the defence industry presupposed either close coordination between the administrative bodies involved or that a single body managed the allocation of orders and the organisation of the industrial restructuring.

The second criterion is making the military production compatible with other production activities in order to cover internal requirements. Therefore, some defence organisations will receive military orders but these will only take up part of their production capacity, so as to allow other activities that could either be of military character and directed towards exports or could be civilian. The degree of state control within this group of organisations will be reduced. This is to say that there would either be privatised organisations with a share in ownership retained by the state or groups would be created among these organisations, the control over which would be more flexible. The latter structures would have particular relevance owing to the fact that they signify a decentralisation in the defence industry's operational decision-making process, which is to say less state intervention at company level.

The third criterion is to establish some defence priorities for the production of certain types of weapons rather than others. Although the setting-up of these priorities should be explicitly approved in the weapons programme, it is arguable whether they would have any specific operational applications, as well as seeming to be conditioned by pressure from the producers themselves, who can introduce significant changes in the decisions which were originally taken. ${ }^{19}$ Nevertheless, given the conditions of the new administrative structure, it was assumed that predominance of the specific interests of influential industrial groups within the sector could be avoided.

The fourth criterion is the introduction of a certain economic rationality within the sector, the application of which would allow organisations from the central nucleus of the defence industry to be detached or even liquidated. Thus, on the one hand, we can point to a reduction in duplicated production or research, opting for concentration in one organisation, which would in addition allow acquisition, upkeep and repair costs to be cut without weakening the country's defensive capability. ${ }^{20}$ On the other hand, there was an emphasis on the elimination of production methods which were inefficient. This was due either to technical considerations, obsolete production methods or failure of organisations to complete their allotted tasks, or to economic ones, by which we mean they were not profitable. ${ }^{21}$ This group also contains some 
organisations that de facto had not had any military orders for a long time, which questioned whether they could really fulfil the desired production requirements. These factors would lead to the exclusion of a significant number of organisations from the defence industry.

The fifth criterion is to increase state control over the organisations which make up the defence industry. The power of the state to name the directors of the state-owned organisations and to name the state representatives in the privatised organisations in whose ownership the state retains some share was specifically underlined. This is to say that the existence of a difference of interest between the the organisations and the state was assumed. The real control over the defence organisations had, up to that moment, been an issue which received scant attention, but in the present restructuring it was given a place of importance.

The sixth criterion is to make the specific reforms possible by adapting them to the existing legal framework. In this respect one of the most important elements in the restructuring refers to the legal status of the state-owned organisations. In the first place, the intention is to create fully state-owned companies (kazennye predpriyatiya) but, as the state has the final say as to the financial obligations of this type of organisation, in the medium term marginal use of this legal form may be expected. ${ }^{22}$ Moreover, some of the military priorities of the research projects would continue to be expressed through the establishment of state-owned scientific centres. Also, one of the most important elements in the restructuring is the creation of associations (integrated structures) based on the privatised organisations. One of the special features of these groups is that they would frequently be coordinated around the acquisition of specific products and would include organisations belonging to different defence industry sub-sectors in such a way as to eliminate some of the obstacles linked to traditional departmentalism. Nevertheless, at the moment there is a great legal vacuum surrounding this area and no legal form is suitable as a back-up to the restructuring policy.

Preparation of the restructuring programme was completed at the end of $1997,,^{23}$ although its application was not legally approved until the end of June $1998,{ }^{24}$ and subsequently the financial crisis has slowed down the programme's anticipated implementation. ${ }^{25}$ Part of the programme was put into practice immediately after it was conceived, and it is interesting to note the approval of the restructuring sub-programme in the field of aviation on 4 September 1997, as it would serve as a trial for the reforms intended to be introduced in the whole sector. ${ }^{26}$ Subsequently, other sub-programmes have also been approved, the most important of these being those in sectors dealing with shipbuilding, radio and electronics, although all of them are guided by the same principles. ${ }^{27}$

\section{The results of the redefining of the state-owned sector}

One of the main tasks of the restructuring was the definition of the group of state-owned organisations. To this end, the list of 480 plants and scientific centres which were not open to privatisation had to be reviewed, and these either consolidated as state-owned or privatised. ${ }^{28}$ As regards the former option, the intention was to promote the creation of fully state-owned companies (kazennye prepriyatiya), yet the 
quantity of resources needed to maintain an organisation of this type still represented a difficult obstacle and as a result only the plants which had previously received this special status were consolidated as such. ${ }^{29}$ This restructuring process came to a standstill and, what is more, these companies were only ever partially financed. ${ }^{30}$ As to the scientific centres, there has been no advance at all in the creation of new GNTs, as the same ones exist as at the end of 1995, while as regards the FNPTs, the situation is different, as at least 12 new groups have been created since the middle of 1997. As to exclusion from the list of organisations not suitable for privatisation, one of the most important decisions was taken in the second half of 1997 when the decision to privatise 26 state-owned companies was taken. ${ }^{31}$ However, subsequent exclusions have been very much one-off in nature as, so far, this process has been practically paralysed.

Decisions taken about the ensemble of privatised defence organisations have had a far-reaching effect. One of the most important measures adopted in the restructuring of the whole defence industry has been the placing of representatives with explicit state-biased interests in privatised defence organisations. ${ }^{32}$ Two classes of representatives can be distinguished; firstly, those placed in the shareholders' assemblies of new joint-stock companies and linked to state ownership of blocks of shares, and secondly, those appointed to the board of directors, related to state ownership of a golden share in privatised organisations. The appearance of these representatives has two important implications. Firstly, an increase in effective state control over defence organisations, which is something that signifies a discrepancy between the interests of the state and those of the people managing plants and scientific centres. Secondly, the body of organisations where explicit state representatives have been designated, together with the list of organisations that are not suitable for privatisation, clearly show up where the state's main interests lie within the defence industry. In this way, the state's priorities within the industry are expressed at the same time as real mechanisms for gaining effective control over the plants and scientific centres are put into practice.

Thus, in the middle of 1998, these three lists created the basis for the design of the future defence sector. There is a central nucleus in the industry made up of 672 organisations (a number equivalent to the 667 which was put forward by the Ministry of Economic Affairs in the restructuring programme ${ }^{33}$ ), among which the true nucleus is represented by the organisations whose privatisation is forbidden-some $478^{34}$ and there is an extension formed by 194 organisations made up of the bodies where the state keeps a controlling block of shares. Around this central nucleus there is a periphery in which we find the organisations where the state has a golden share (these total 192); these, seemingly, will be excluded from the future defence industry. The remaining organisations from the old defence industry will be freely privatised. This organisational structure was subsequently strengthened when a list of strategic defence organisations was approved.$^{35}$ This updated another list which was approved in $1995^{36}$ which, in essence, coincided with the list of privatised organisations where the state appointed representatives in the shareholders' assemblies. ${ }^{37}$ In line with this, some modifications in the enlarged defence industry nucleus were introduced, which were frequently associated with the creation of corporate structures (integrated structures) but, essentially, the nucleus has kept its initial form. 
TABLE 2

Definition of the Structure of the Defence Industry

\begin{tabular}{lccccc}
\hline & I. & II. & $\begin{array}{c}\text { III. } \\
\text { Second-level } \\
\text { priority } \\
\text { privatised } \\
\text { companies }\end{array}$ & $\begin{array}{c}\text { Central } \\
\text { nucleus }\end{array}$ & $\begin{array}{c}\text { Enlarged } \\
\text { nucleus }\end{array}$ \\
\hline Aviation & $\begin{array}{c}\text { State } \\
\text { companies }\end{array}$ & $\begin{array}{c}\text { comprity } \\
\text { privatised }\end{array}$ & 14 & 141 & 155 \\
Ammunition & 45 & 96 & 3 & 100 & 103 \\
Armament & 93 & 7 & 30 & 81 & 111 \\
Communications & 60 & 21 & 27 & 67 & 94 \\
Radio & $50(51)$ & 17 & 24 & 90 & 114 \\
Space & 73 & 17 & 30 & 64 & 72 \\
Shipbuilding & 60 & 18 & 56 & 71 & 101 \\
Electronics & $53(54)$ & 14 & 192 & 672 & 114 \\
Total & 44 & 194 & & & 864 \\
\hline
\end{tabular}

Column I. Corresponds to the organisations whose privatisation was prohibited in the 1996 list. In the rows where there are figures in brackets those correspond to that list, whereas those which are outside the brackets are worked out by subtracting the state-owned organisations, those which also appeared in the 1998 list, from strategic privatised businesses (Column II), which is to say that their privatisation had already been decided on.

Column II. These are the organisations where the state names representatives in the assemblies of shareholders, a decision derived from the ownership of a block of shares.

Column III. These are the organisations where the state names representatives on the boards of directors (of the privatised organisations), this being linked to control over the decision-making process derived from the existence of a golden share.

Column IV. The sum of columns I and II.

Column V. The sum of columns I, II and III.

Sources: Own elaboration from Postanovlenie pravitel'stvo RF 'O perechne predpriyatii i organizatsii oboronnogo kompleksa, privatizatsiya kotorykh zapreshchena', no. 802, 12 July 1996; and Postanovlenie Pravitel'stva RF 'O naznachenii predstavitelei gosudarstva $\mathrm{v}$ otkrytykh aktsionernykh obshchestvakh oboronno-promyshlennogokompleksa', no. 388, 7 April 1998.

Another wide-reaching change that occurred halfway through 1998 was the reassignment of organisations from the Ministry of Economic Affairs ${ }^{38}$ to the Russian Space Agency (Rossiiskoe kosmicheskoe agenstvo-RKA). This change initially affected 65 organisations, part of whose output was space-related, as well as others, especially military ones, which did not belong to this sub-sector but which greatly affected the space programmes. ${ }^{39}$ The RKA could stimulate part of the restructuring by privatising, grouping together or excluding these organisations from the defence industry. ${ }^{40}$

It is important to point out that the RKA is made up of the organisations most deeply involved in the production of strategic missiles and, in particular, those which are developing the Topol'-M programme (SS-27). It must be underlined that, after experiencing several problems not only in the past ${ }^{41}$ but even in the present day ${ }^{42}$ this programme enjoys maximum priority within the defence industry. This programme is itemised separately among the state's military orders in the federal budget and the arrears relating to these orders enjoy preference in payment. ${ }^{43}$ Taking the designation of the organisations to take part in the construction of these strategic missiles as a starting point, one of the essential functions of the RKA is to guarantee the fulfilment of this first-rank military priority. 
On the other hand, and although after the above-mentioned reorganisation only some of the space organisations came under the jurisdiction of the RKA, there did exist a trend towards placing all the plants and scientific centres in this sub-sector under the responsibility of this body. It is important to note that the organisations from the aviation sub-sector were subsequently incorporated into the $\mathrm{RKA}^{44}$ but, given the heterogeneous nature of the resulting group, which had diverging or even opposing interests, ${ }^{45}$ the appearance of internal tensions within the new administrative body is foreseeable. Nevertheless, it must be stressed that, as the RKA was an administrative body at an inferior level to the Ministry, the latter still had, in the last resort, the final say over the restructuring in the aerospace field.

One aspect that has an important impact on the restructuring is the management of military orders. To this end, responsibility for placing state military orders was moved from the Defence Ministry to the Ministry of Economic Affairs, so that the latter enjoyed a role of greater importance in promoting the sector's restructuring. ${ }^{46}$ The aim was to avoid further financial problems and and irregularities in placing orders, and particularly to deal with the state's enormous debt to the defence organisations, by concentrating these issues in one institution only. Thus the intention was to solve once and for all one of the most serious problems which had appeared in the previous period of restructuring; the breach existing between the fulfilment of military orders, their financial support and the reorganisation of the defence industry. At the same time, the first steps were taken towards tackling the question of weapons standardisation. To this end, a commission whose aim is to optimise military orders has begun to operate, ${ }^{47}$ which should develop this vital aspect in order to direct the restructuring of the defence industry.

One of the aspects of the reorganisation of the defence industry which has received most attention has been the creation of corporate structures (integrated structures). The absence of any legislation which would contribute to solving the sector's problems has been a difficulty in this regard which has had to be faced. Traditionally, some of these integrated structures had chosen their names randomly (for example kontsern, kompleks or korporatsiya), whereas those which enjoy legal status (holding companies or financial-industrial groups-FIG) present too many limitations if they are to be used as a generalised reference for the sector's restructuring. ${ }^{48}$ Given these legal limitations, and regardless of the name of the integrated structure, the restructuring policy has committed itself to setting up associations. These adopted the legal form of a limited company where the state owned the majority share, at the same time as the association took over the shares which the state held in the businesses and scientific centres which belonged to the association. In terms of productivity, the association will coordinate the activities of the member organisations with the aim of obtaining one or two types of weapons systems and will maintain its decision-making capacity and control over the property of the member organisations.

Aviation is one sub-sector that has been used as a platform for experimentation. In 1997 a restructuring programme was established for this sub-sector in such a way as to set up a first level of defence associations with a total of five to six integrated structures, where those taking part would be grouped around the assembly of specific end products: fighter planes, helicopters, heavy bombers, etc. These associations could include, at least, centres of design, experimentation and mass production. 
On the other hand, a second level of associations would be established where there would be some 10-15 corporate structures and whose aim would be to produce aircraft accessories, parts or components such as engines, weapons, special materials etc. Their production, though, would not be exclusively for military purposes. ${ }^{49}$

Two associations stand out as enjoying the highest prority owing to their connections with weapons production-AVPK Sukhoi and VPK MAPO, which, more over, were used as pilot experiments during the restructuring. The rest of the industrial groups, meanwhile-Il'yushin, Tupolev, Yakovlev and Milya-could take a secondary position. AVPK Sukhoi was created during the second half of 1996 and grouped together the main organisations related to the design and assembly of Su aeroplanes. The setting-up of the group began in the second half of 1997 when the companies that were still state-owned were allowed to be 'privatised' and their shares had to be transferred to the integrated structure. ${ }^{50}$ At the beginning of 1998 the integrated structure was transformed into a joint-stock company in which the state owned $100 \%$ of the shares, ${ }^{51}$ and changes were introduced in the board of directors. ${ }^{52}$ The internal restructuring will continue until both the decision-making process and the financing are centralised.$^{53}$ As regards this latter point, the first steps towards establishing the group have been subject to many conflicts due to the reluctance on the part of the board of directors of the member organisations to lose their autonomy. ${ }^{54}$ The group VPK MAPO established its nucleus in 1995 when the company Moskovskoe aviatsionnoe PO im. P.V. Dement'eva (MAPO) absorbed the design centre OKB im. Mikoyana i Gurevicha (MiG) (also in Moscow). Subsequently, in 1996, the VPK MAPO was set up, which grouped together the greater part, although not all, ${ }^{55}$ of the strategic organisations for the production of $\mathrm{MiG}$ aeroplanes (12 organisations in total), besides incorporating organisations not connected to the production of MiG. ${ }^{56}$ Halfway through 1997 there was a change of directors ${ }^{57}$ and new companies were introduced $^{58}$ with the aim of consolidating it as a corporate structure.The rest of the associations in the aviation sub-sector are in the course of being formed but prospects of them being established as integrated structures of definite military importance are doubtful. Several initiatives to create a business association around the design centre ANTK im. A. N. Tupolev (Moscow) have taken place, but the setting up of Aviastroitel'naya kholdingovaya kompaniya Tupolev halfway through 1997 has been the most serious attempt yet to form an integrated structure ${ }^{59}$ This association is of civilian importance, ${ }^{60}$ yet its military production is of little significance for the state. There was also a plan to set up an association around the ANTK im. Il'yushina (Moscow) design centre, but this has been hindered because one of the factories is in Tashkent. ${ }^{61}$ At the end of 1997 fresh impetus was given to setting up this integrated structure through the creation of the Aviastroitel'naya kompaniya Il'yushin, of which the state will own at least $51 \%$ of the shares. In this case there is a two-phase plan for the creation of the international association: firstly, the group would include two Russian defence organisations, which would at least transfer to the group the state-held block of shares, and subsequently the company in Tashkent would be incorporated ${ }^{62}$ It is worth pointing out that the essential activity of the group would be civilian in nature, leaving military production in the background. ${ }^{63}$ As regards the associations set up around the OKB im. Milya (Moscow) and OKB im. Yakovleva 
(Moscow) design centres, these are still in the first stage of construction. However, both centres present serious problems when it comes to being established as associations, due as much to the reluctance on the part of the organisations in question to join the corresponding association (for example, the case of Korporatsiya Vertolety $\mathrm{Mi}^{64}$ ) as to the absence of military priority for their production.

At the second level of integrated structures, a certain restructuring has also taken place. Specifically, the group of businesses to be excluded from the defence sector has been more accurately defined, and this is a decision which limits the formation of integrated associations within this sub-sector. An outstanding example of this is that, out of the 15 engine manufacturers active at the moment, only three to four will be kept within the defence industry. ${ }^{65}$ Besides supporting the consolidation of the associations which have already been set up, the Korporatsiya Aerokosmicheskoe oborudovanie has been created, which is closely connected to the developing of military priorities and over which the state exercises special control. ${ }^{66}$ To the same end, a group made up of four more organisations is being created around the NPP Aerosila (Stupino, Moscow oblast') whose aim is to manufacture aircraft engines, both for civilian and military purposes. ${ }^{67}$

The intention of the rest of the defence industry's sub-sectors is to follow the trend set by aviation, but they do not yet seem to be as advanced. In the radio sub-sector, for example, the creation of this type of association structure is still in its primary phase and the government has focused its efforts on the already existing structures. The FIG Oboronitel'nye sistemy, created in 1997, is an outstanding example. Here the majority of the organisations in the association are state-owned or, if they do happen to be privatised, the state holds a sizeable block of shares in them. ${ }^{68}$ Secondly, meanwhile, we can consider the case of the Kontsern Antei, which was created in 1991 but has since raised the number of participating groups to $15 .^{69}$ The peculiarity of both organisations is their specialisation in the design and manufacture of air defence complexes, the production of which is of great military importance.

In the rest of the defence industry sub-sectors the Ministry of Economic Affairs restructuring has been of a more modest nature. Nevertheless, the creation of new integrated structures has also been promoted in the electronics sub-sector. This has been done specifically via the setting up of at least two holding companies; the first of a more civilian nature, and the second more military. The former, Rossiiskaya Elektronika, ${ }^{70}$ over which the state continues to enjoy a substantial degree of control, groups together 31 plants and research centres. One special feature of this holding company is that its aim is to carry out the presidential programme 'Razvitie elektronnoi tekhniki v Rossii', at the same time as it makes up the nucleus of an international association, FIG international Elektronnye tekhnologii (FIG Eletekh). ${ }^{71}$ The creation of the holding company Voennya elektronika ${ }^{72}$ represents the second relevant attempt to create a business group within the electronics sub-sector. This military holding company, which will have its nucleus in Novosibirsk, is in the process of being created, although its very establishment could be questioned owing to the bad economic state of the groups which make it up. ${ }^{73}$

Owing to the number of types of integrated structures (associations) and the short time they have been in existence, it is difficult to be precise as to their impact on the 
defence sector as a whole. This situation is even more difficult to assess in so far as one of the objectives focused on has been the setting up of the groups. Nevertheless, we should underline the qualitative advances made in the pilot experiments in the aviation sector. In short, at the end of 1998, some 200 defence organisations were to be found incorporated into integrated structures whose activity was directed towards military production. To sum up, therefore, the impact of the creation of integrated structures on the defence industry as a whole is small but steadily increasing.

\section{Limits to the restructuring policy}

The Ministry of Economic Affairs restructuring policy has meant a change of focus for the defence industry reforms, characterised by greater realism. Nevertheless, it is worth pointing out that the original aims were too ambitious given the economic situation in both the country and the sector itself. As a result, and although far-reaching measures have been adopted, the results in many cases have turned out to be partial. However, it must be stressed that modifications to the initial approach of the restructuring programme have begun to be introduced in certain areas, as is obvious from looking at the aviation sub-sector, which is where this type of change has advanced the furthest.

One area where only partial decisions have been taken is at the sectoral level. An extreme example of a sub-sector where hardly any decisions have been taken, especially those related to the exclusion of organisations from the sector, is that of ammunitions and special chemicals, a situation justified by the excessive specificity and heterogeneous nature of this activity. ${ }^{74}$ There is a very high degree of state participation within the sector, and even in the case of privatised organisations the state presence is considerable. Furthermore, it must be pointed out that a not inconsiderable number of the companies has received no orders since the beginning of the transition. ${ }^{75}$ Therefore, this lack of decision making, coupled with the contraction in both defence and export needs, together with the major financial problems, ${ }^{76}$ will lead to a significant cut in the number of organisations in the sub-sector.

The second area where there exists a definite lack of any decision making is in the integrated structures themselves. In the aviation sub-sector, for example, a total of six integrated structures were initially decided on, but their future prospects are very different. Whereas the AVPK Sukhoi is to be found in the very heart of the defence industry, since it is possible to concentrate the most urgent priorities in the building of military aircraft there, the situation of the VPK MAPO is in doubt. To be more specific, the naming of an ex-director of Sukhoi as director general of the MAPO association may suggest the take-over of the second group by the first, thereby concentrating the main body of military aircraft and helicopter construction priorities. ${ }^{77}$ As to the rest of the groups, their continued place within the defence industry is in doubt. The exclusion of the organisations connected to OKB im. Milya and OKB Yakovleva from the defence industry is especially likely. As regards the Tupolev and Il'yushin groups, which manufacture an important amount of products for civilian purposes, they will be found, at the very best, on the edge of the defence industry, due either to the lack of military orders or to their precise nature. Therefore, out of 
more than six integrated structures, it is possible that only one will continue to find a place within the defence industry. A similar situation with the manufacture of air defence complexes may arise in the radio sub-sector. ${ }^{78}$ The long-range air defence complexes, in particular, are of primary importance and it seems likely that the FIG Oboronitel'nye sistemy will cover this requirement. Given the tendency towards standardising arms and eliminating organisations that fulfil similar production requirements, the Kontsern Antei would become of second-grade importance and may see its position in the structure of the defence industry visibly altered. $^{79}$

In the third place, a situation similar to that surrounding the integrated structures is arising at plant level, owing to the concentration of orders on one type of weapons and the desire to avoid product duplication. In the armament sub-sector, for example, the state's priorities as regards greater control over the organisations themselves have been especially focused on those which are directly involved in weapons manufacture. Nevertheless, within this type of activity there is an order of precedence that seems to be influenced by the actual type of weapons made, as well as by the decisions taken regarding the standardisation of weapon types or any overlapping production. However, the exclusion from this sector of organisations carrying out this type of activity has been partial, and one example which illustrates this is that of the manufacture of tanks. When the USSR split up, four companies in this line of production remained on Russian territory, but only two carried on actively producing and kept their rank of state-owned companies: Uralvagonzavod (Nizhnii Tagil, Sverdlovsk oblast') and Omskii zavod transportnogo mashinostroeniya (Omsk). Nevertheless, the tendency towards maintaining only a modest demand for this type of vehicles has been consolidated, ${ }^{80}$ and for this reason, as well as a decision taken in 1996 to standardise orders for T-90 class tanks ${ }^{81}$ alone (manufactured by Uralvagonzavod), the exclusion of the Omsk factory from the defence industry is foreseeable.

A fourth area where partial decisions have been taken is related to the exclusion of military priorities owing to problems of technical development. The manufacture of strategic missile-carrying atomic submarines is included in this area. In this case, there are important obstacles to developing new-generation strategic missiles to place in this class of submarine and, as a result, the essential element that could give this type of craft top priority is missing. Furthermore, the excessive costs involved in constructing submarines of this class are no incentive. ${ }^{82}$ The combination of both of these problems leads us to consider the situation of both the manufacture of atomic military submarines and the aforementioned classes of missiles to be a marginal one within the area of arms priorities, and the prospects for the companies related to both lines of production therefore come under question. It is important to emphasise that the fall in the importance given to atomic submarines benefits the demand prospects of the diesel-class ones, particularly those manufactured by the FIG Morskaya tekhnika (St Petersburg), ${ }^{83}$ where they are developed. What is more, one feature of this association is that it could cover the modest requirement to build large military ships through one of its member companies, Admiralteiskie verfi (St Petersburg) ${ }^{84}$

In fifth place, it seems that the combining of arms production to cover both internal and export needs has not been given enough consideration. Some of the second-level military production lines can be combined by boosting exports, so that the production 
costs are partially covered by the demand from foreign customers. In fact, this would mean adapting military priorities to economic conditions, although it would avoid any worsening in the scientific-technological level of some organisations at the same time as permitting the continued supply to the armed forces of weapons which, while not quite the most innovative available, are of good enough quality. Most of the financial-industrial groups created with a specifically military profile could respond to this type of situation.

\section{Conclusion}

From summer 1997 onwards the government's economic policy regarding the restructuring of the defence industry has been a relatively active one. This has been conditioned by the desire to cover any arms needs. Although the lack of a coherent and clearly defined arms programme is a hindrance when it comes to giving direction to the restructuring policy, some arms priorities have emerged (either in the shape of preferences in the supply of arms or of exclusion of military activities) which have shaped the policies pursued.

The present restructuring has allowed the defence industry to be redefined, at the same time as introducing new management mechanisms within the sector. On the first point, the number of organisations belonging to the sector has been significantly cut and will decrease even more in the future if the criteria behind this restructuring are applied more strictly. As to the second point, the basic aim of the restructuring policy has been to create integrated structures, legally regarded as joint-stock companies, in which the state holds a block of shares; the more important the association's military priority, the bigger the block. In this way, the state possesses a mechanism of control over the activity of the business ensemble, and particularly the military side, at the same time as distancing itself from the running and financing of these groups. Likewise, on the one hand, these associations become instruments to extend the use of economic criteria in the defence sector's working guidelines and, on the other, they permit the introduction of subsequent restructuring within the groups, so that a later reduction in the size of the sector may be achieved.

What is more, from among the new ways of running the sector, the state's interest in increased control over the defence organisations must be stressed. An active management renovation policy has been developed via the direct appointment of the boards of directors in the state-owned organisations and through the naming of state representatives in the shareholders' assemblies and on the boards of directors in the privatised ones.

The restructuring policy has created a framework within which changes in the manufacture of arms in the defence industry can be developed. The aim is to manufacture a smaller quantity of arms but to a high degree of quality (with high-level technological components and very advanced performance), but only following certain top-priority lines (selectively chosen) and more closely adapted to the emergence of regional military conflicts. One exception to this is the upkeep of massive destruction nuclear weapons, although markedly fewer than during the Soviet period. The achievement of such objectives will appear to be qualified in a period of transition in which part of the arsenal inherited from the Soviet period will be kept 
active. The modernisation of the weapons will allow them either a longer life-span or a widening (or improvement) of their functions at a relatively low cost, and will make the transition easier.

University of Valencia

This research has been made possible thanks to the help of the Valencian local government's council of education, science and culture. Furthermore, this article is indebted to the comments and suggestions of Julian Cooper (CREES, Birmingham University, UK), while in its first stages.

${ }^{1}$ Postanovlenie pravitel'stvo RF 'O perechne predpriyatii i organizatsii oboronnogo kompleksa, privatizatsiya kotorykh zapreshchena', no. 802, 12 July 1996.

${ }^{2}$ Antonio Sánchez-Andrés, 'Privatisation, Decentralisation and Production Adjustment in the Russian Defence Industry', Europe-Asia Studies, 50, 2, 1998, p. 245.

${ }^{3}$ I. Labrushenkova \& A. Voyakina, 'Institutsional' nye preobrazovaniya v oboronnom komplekse', Voprosy ekonomiki i konversii, 1996, 1, p. 58.

${ }^{4}$ Civil Code of the Russian Federation, art. 113 and 115 and Postanovlenie pravitel' stva RF 'O poryadke planirovaniya i finansirovaniya deyatel'nosti kazennykh zavodov (kazennykh fabrik, kazennykh khozyaistv)', no. 1138, 6 October 1994.

${ }^{5}$ Note that this number of companies approximately coincides with the GKOP estimate of the future number of state-owned organisations, set out in Table 1. See Ekspert, 1996, 20, p. 33 and Rasporyazhenie pravitel' stva RF, no. 125-r, 28 January 1997.

${ }^{6}$ This distinction in the type of scientific centres partially reproduces the traditional difference in the field of scientific activities between NPO and NII (or KB). See Marianna Afanasieva \& Marie L. Couder, 'Restructuring of R\&D Organisations and the Defence Industry in the Russian Federation', Journal of Applied Management Studies, 7, 1, 1998, pp. 36-37.

${ }^{7}$ See 'Gosudarstvennye nauchnye tsentry oboronnogo kompleksa', Konversiya, 1995, 12, pp. 11-13; Yu. Zhbanov, 'Regional'nye aspekty konversii v Rossiiskoi Federatsii', Konversiya, 1996, 1, p. 3 and NITs PEU, 'Deistvuyushchaya struktura oboronno-promyshlennogo kompleksa Rossii'. http://www.vpk.ru:8082/www-vpk/vit/stat2.htm. January 1998.

${ }^{8}$ Antonio Sánchez-Andrés, 'The Transformation of the Russian Defence Industry', Europe-Asia Studies, 47, 8, 1995, pp. 1272-1274; and Julian Cooper, 'The Future Role of the Russian Defence Industry', in Roy Allison \& Christoph Bluth (eds), Security Dilemmas in Russia and Eurasia (London, 1998), pp. 107-110.

${ }^{9}$ E. Lensky \& V. Tsvetkov, Finansovo-promyshlennye gruppy: istoriya sozdaniya, mezhdunarodnyi opyt, rossiiskaya model' (Moscow, 1997), pp. 157-182; and V. Dementev, 'Finansovo-promyshlennye gruppy v rossiiskoi ekonomike. Tema-1', Rossiikii ekonomicheskii zhurnal, 1998, 5, pp. 82-83.

${ }^{10}$ Finansovye izvestiya, 23 July 1998, p. 2.

${ }^{11}$ Postanovlenie pravitel'stva RF 'O kontseptsii restrukturizatsii oboronno-promyshlennogo kompleksa Rossiiskoi Federatsii’ , n¹057, 20 August 1997. See http://www.vpk.ru:8082/www-vpk/vpk/ restr.htm. January 1998.

${ }^{12}$ This type of programme assumes the traditional hypothesis that the greater part of domestic arms manufacture costs should be covered by domestic demand while exports will be a complementary element reducing the total cost. On these matters see Kelvin P. O'Prey, The Arms Export Challenge. Cooperative Approaches to Export Management and Defense Conversion (Washington, DC, 1995), p. 5 .

${ }^{13}$ To this end, the statements of Urinson, the Minister of Economic Affairs, are illustrative, as he does not acknowledge the defence industry to be an integrated complex, at the same time as underlining the need to apply economic criteria to the sector. See Russkii telegraf, 20 March 1998, p. 4.

${ }^{14}$ Nezavisimaya gazeta, 26 December 1997, p. 2.

${ }^{15}$ Krasnaya zvezda, 17 January 1998, p. 3.

${ }^{16}$ Sharon Leiter, Prospect for Russian Military R\&D (Santa Monica, 1996), p. 69.

${ }^{17}$ Krasnaya zvezda, 5 November 1997, p. 1.

${ }^{18}$ Delovoi mir, 11-15 December 1997, p. 7.

${ }^{19}$ It must not be forgotten that manufacturers have traditionally been a very important agent in the defining of priorities, as well as having been able to impose their own criteria on the armed forces. See Peter Almquist, 'Soviet Military Acquisition: From a Sellers's Market to a Buyers'?', in Susan L. Clark (ed.), Soviet Military Power in a Changing World (Boulder, 1991), pp. 133-151.

${ }^{20}$ Nezavisimoe voennoe obozrenie, 1997, 40, p. 6 and 1998, 19, p. 4. 
${ }^{21}$ These phenomena are connected to the defence industry's worsening economic conditions, especially the growing obsolescence due to the lack of investment, the ageing workforce and the loss of workers, particularly those most highly qualified.

${ }^{22}$ On different aspects of the fully state-owned companies see E. Torkanovsky, 'Gosudarstvennoe predprinimatel' stvo: organizatsionno-pravovye formy', Voprosy ekonomiki, 1995, 12, p. 78; and A. Akhmeduev, 'Kazennye predpriyatiya: funktsii, kriterii i mekhanism khozyaistvovaniya', Ekonomist, 1998, 9, pp. 79-83.

${ }^{23}$ Inzhenernaya gazeta, 1997, 72, p. 1.

${ }^{24}$ Nezavisimoe voennoe obozrenie, 1998, 28, pp. 1 and 6.

${ }^{25}$ Nezavisimoe voennoe obozrenie, 1998, 35, p. 1.

${ }^{26}$ Nezavisimaya gazeta, 4 December 1997, p. 1.

${ }^{27}$ Interview with Aleksandr Kabanov, Ministry of Economic Affairs, Moscow, 12 May 1999.

${ }^{28}$ Segodnya, 28 August 1997, p. 6.

${ }^{29}$ Postanovlenie pravitel' stva RF 'Ob utverzhdenii ustavov federal' nykh kazennykh predpriyatii Voskresenskii gosudarstvennyi kazennyi agregatnyi zavod, Verkhnesaldinskii gosudarstvennyi kazennyi zavod khimicheskikh emkostei i Girsovskii gosudarstvennyi kazennyi zavod pirotekhnicheskikh sredstv', no. 642, 26 May 1997.

${ }^{30}$ Interview with Viktor Rassadin, Economic Forecasting Institute, Moscow, 6 May 1999.

${ }^{31}$ Additionally, the sale of blocks of state-owned shares in 11 previously privatised defence companies was anticipated. See Kommersant', 1997, 31, p. 43.

${ }_{32}$ Postanovlenie Pravitel'stva RF 'O naznachenii predstavitelei gosudarstva v otkrytykh aktsionernykh obshchestvakh oboronno-promyshlennogo kompleksa’, no. 388, 7 April 1998.

${ }^{33}$ Nezavisimaya gazeta, 26 December 1997, p. 2.

${ }^{34}$ Originally there were 480 organisations, but two of these were found in the list of limited companies in which the state had representatives in the share holders' assemblies. To be specific, these two organisations were NPO Krasnaya zarya (St Petersburg) (belonging to the communications sub-sector) and Khabarovskii sudostroitel' nyi zavod im. 60letiya SSSR (Khabarovsk) (in the shipbuilding sub-sector).

${ }^{35}$ Postanovlenie pravitel'stva RF 'O perechne aktsionernykh obshchestv, proizvodyashchikh produktsiyu (tovary, uslugi), imeyushchuyu strategicheskoe znachenie dlya obespecheniya natsional'noi bezopasnosti gosudarstva, zakreplennye v federaln' noi sobstvennosti aktsii kotorykh ne podlezhat dosrochnoi prodazhe', no. 784, 17 July 1998; and Postanovlenie pravitel'stva RF 'O dopolnenii perechnya aktsionernykh obshchestv, proizvodyashchikh produktsiyu (tovary, uslugi), imeyushchuyu strategicheskoe znachenie dlya obespecheniya natsional' noi bezopasnosti gosudarstva, zakreplennye $\mathrm{v}$ federaln' noi sobstvennosti aktsii kotorykh ne podlezhat dosrochnoi prodazhe', no. 246, 27 February 1999.

${ }^{36}$ Postanovlenie pravitel' stva RF 'O perechne aktsionernykh obshchestv, sozdannykh v protsesse privatizatsii, proizvodyashchikh produktsiyu (tovary, uslugi), imeyushchuyu strategicheskoe znachenie dlya obespecheniya natsional' noi bezopasnosti gosudarstva strany, zakreplennye $v$ federaln' noi sobstvennosti aktsii kotorykh ne podlezhat dosrochnoi prodazhe', no. 949, 18 September 1995.

${ }^{37}$ Specifically, out of the 194, 167 organisations coincide, although in certain cases the state-owned block of shares is found to be smaller. Out of the 27 organisations which are not now considered to be strategic, several are joined together in associations controlled by the state and this questions the reductions set out in these last lists. On the other hand, it is worth pointing out that there were 15 organisations that appeared in the 1998 and 1995 lists, but not in the one where there were explicit state representatives. Lastly, in the 1998 list, there are three cases of organisations considered as strategic for the first time, as well as associations.

${ }^{38}$ Postanovlenie pravitel' stva RF 'O merakh po vypolneniyu Ukaza Prezidenta Rossiiskoi Federatsii ot 20 yanvarya $1998 \mathrm{~g}$ ', no. 54; 'O realizatsii gosudarstvennoi politiki $\mathrm{v}$ oblasti raketno-kosmicheskoi promyshlennosti’, n440, 12 May 1998.

${ }^{39}$ It must be pointed out that in the official list there are two sub-lists, the first corresponding to the state-owned organisations (in total 38) and the second to the privatised organisations (in total 21). Nevertheless, out of the state-owned organisations, one, the NPO Orion (Krasnoznamensk, Moscow oblast'), groups together six companies, while the NPTs im. Pilyugina (Moscow) is made up of two centres from the list of organisations not suitable for privatisation of July 1996. Thus the number 65 is reached.

${ }^{40}$ Nezavisimaya gazeta, 20 December 1997, p. 1.

${ }^{41}$ Kommersant', 1998, 39, pp. 28-29.

${ }^{42}$ Segodnya, 27 October 1998, p. 2.

${ }^{43}$ Krasnaya zvezda, 15 October 1997, p. 3.

${ }^{44}$ Kommersant'-Daily, 29 April 1999, p. 7. 
${ }^{45}$ Inzhenernaya gazeta, 1999, 16, p. 1.

${ }^{46}$ Russkii telegraf, 3 April 1998, p. 4.

${ }^{47}$ Postanovlenie Pravitel' stva RF 'Ob obrazovanii Mezhvedomstvennoi komissii po optimizatsii gosudarstvennogo oboronnogo zakaza', no. 614, 19 June 1998.

${ }^{48}$ Ukaz prezidenta $\mathrm{RF}$ ' $\mathrm{O}$ merakh po realizatsii promyshlennoi politiki pri privatizatsii gosudarstvennykh predpriayatii', no. 1392, 16 November 1992, prilozhenie no. 1, 'Vremennoe polozhenie o kholdingovykh kompaniyakh, sozdavaemykh pri preobrazovanii gosudarstvennykh predpriyatii v aktsionernye obshchestva'; Ukaz prezidenta RF 'O sozdanii finansovo-promyshlennykh grupp v Rossiiskoi Federatsii’, no. 2096, 5 December 1993; Polozhenie o finansovo-promyshlennykh gruppakh i poryadke ikh sozdaniya, and Federal'nyi zakon RF 'O finansovo-promyshlennykh gruppakh', no. 190-FZ, 30 November 1995; and S. Tolkachev, 'Konkurentnye strategii rossiiskikh oboronnykh kompanii', Rossiiskii ekonomicheskii zhurnal, 1998, 1, p. 53.

${ }^{49}$ Krasnaya zvezda, 13 September 1997, pp. 3 and 5.

${ }^{50}$ Kommersant', 1997, 31, p. 43; and Krasnaya zvezda, 13 September 1997, p. 3.

${ }^{51}$ Segodnya, 13 January 1998, p. 5; and Nezavisimoe voennoe obozrenie, 1998, 19, p. 6.

${ }^{52}$ At the beginning of 1998 there was a particularly interesting case when a new director of the group was appointed by the Ministry of Economic Affairs, thereby removing one of the traditional defence industry directors from the head of the association. This is to say that the Ministry of Economic Affairs laid great importance on the renewal of strategic posts within the most relevant organisations during the restructuring. In this way, they hoped to get rid of the burdens and prejudices of the old directors. On the conception of the restructuring of the group from the point of view of the new director of the Sukhoi group see, Russkii telegraf, 31 March 1998, p. 7.

${ }_{53}$ Russkii telegraf, 8 April 1998, p. 7.

${ }^{54}$ Izvestiya, 25 July 1997, p. 5.

${ }^{55}$ It did not include, for example, the Nizhegorodskii aviatsionnyi zavod Sokol (Nizhnii Novgorod), which manufactures several classes of MIG aircraft. See Inzhenernaya gazeta, 1994, 121, p. 2.

${ }_{56}$ The helicopter design centre VNTK im. Kamova, for example. See Kommersant'-Daily, 16 April 1996, p. 2; and Nezavisimoe voennoe obozrenie, 1997, 13, p. 6.

${ }_{57}$ Ekspert, 1998, 12, pp. 30-32.

${ }^{58}$ In particular, Eksperimental' nyi zavod im. Myasishcheva (Zhukovskii, Moscow oblast') and Arsen' evskoe aksionernoe ob"edinenie Progress (Arsen' ev, Primorskii krai). See Kommersant'-Daily, 25 June 1997, p. 10; Inzhenernaya gazeta, 1997, 35, p. 2; and B. Mil'ner, 'Krupnye korporatsii-osnova pod"ema i uskorennogo razvitiya ekonomiki', Voprosy ekonomiki, 1998, 9, p. 72.

${ }^{59}$ Rasporazhenie pravitel' stva RF, no. 972-r, 10 July 1997.

${ }^{60}$ Kazanskoe aviatsionnoe PO im. S.P. Gorbunova (Kazan'), whose activities have been reduced to the manufacture of class Tu-160 and Tu-22 M bombers, has not, at the moment, been included in this group. See Military Parade, January-February 1994, p. 44.

${ }_{61}^{61}$ RIKA, 1992, 13, pp. 2-4.

${ }^{62}$ Ukaz prezidenta 'O dal' neishem razvitii integrirovannykh aviastroitel' nykh kompleksov', no. 1453, 2 December 1998.

${ }^{63}$ Russkii telegraf, 4 June 1998, p. 5.

${ }^{64}$ Rossiiskaya gazeta, 4 January 1998, p. 12; and Ekspert, 1998, 35, p. 43.

${ }^{65}$ Inzhenernaya gazeta, 1998, 23-24, p. 1.

${ }^{66}$ See Postanovlenie pravitel'stva Rossiiskoi Federatsii 'O sozdanii otkrytogo aktsionernogo obshchestva Korporatsiya Aerokosmicheskoe oborudovanie’, no. 1347, 14 November 1998.

${ }^{67}$ Vechernyaya Moskva, 20 April 1999, p. 4.

${ }^{68}$ Krasnaya zvezda, 26 April 1997, p. 3; and Voennye znaniya, 1997, September, p. 22.

${ }^{69}$ Russkii telegraf, 19 March 1998, p. 1.

${ }^{70}$ Postanovlenie pravitel' stva RF 'O merakh po realizatsii Ukaza Prezidenta Rossiiskoi Federatsii ot 23 Iyulya $1997 \mathrm{n}^{\circ} 764$ 'O dopolnitel'nykh merakh po povysheniyu effektivnosti realizatsii prezidentskoi programmy 'Razvitie elektronnoi tekhniki v Rossii', ,, no. 1583, 18 December 1997.

${ }_{71}^{71}$ Russkii telegraf, 21 August 1998, p. 4.

${ }^{72}$ Russkii telegraf, 22 April 1998, p. 5.

${ }^{73}$ This is the case with the three state-owned organisations Novosibirskii zavod radiodetalei Oksid, Zavod poluprovodnikovykh priborov and NPP Vostok. See Inzhenernaya gazeta, 1992, 91, p. 2; Krasnaya zvezda, 21 August 1993, p. 4; and Delovaya sibir', 1996, 33, p. 6.

${ }^{74}$ Nezavisimoe voennoe obozrenie, 1997, 34, p. 6.

${ }^{75}$ From among some cases of state-owned plants we can note Zavod Kommunar (Kemerovo) and Biiskoe PO Sibpribormash (Biisk, Altai). See A. I. Lyubin, 'Potentsial promyshlennosti proizvodstva boepripasov i spetskhimii', Voprosy ekonomiki i konversii, 1995, 1, p. 65.

${ }^{76}$ In 1996, for example, a special federal programme for the sector, 'Spetskhimiya', was approved 
but no financing was found for it. See Postanovlenie pravitel' stva RF 'O Federal' noi tselevoi programme razrabotki i primeneniya tekhnologii dvoinogo naznacheniya "Spetskhimiya", no. 1012, 26 August 1996, and Rossiiskie vesti, 23 October 1996, p. 2.

${ }_{77}$ Vremya, 4 February 1999, p. 4; and Nezavisimaya gazeta, 5 February 1999, p. 2.

${ }^{78}$ Tolkachev, pp. 52-53.

${ }^{79}$ Delovye lyudi, 1999, 97, pp. 29-30.

${ }^{80}$ In 199220 tanks were ordered, and although there was a rise in subsequent demand it was not a significant one. In 1995, for example, 60-80 were ordered and in 1996, only 58. See Steven Zaloga, 'T-90: The Standard of Russian expediency', Jane's Intelligence Review, 9, 2, 1997, pp. 58-64.

${ }^{81}$ The decision was found to be particularly justifiable due to the arguable results obtained by the T-80 produced by this company during the Chechen war, as well as to the technical problems encountered in manufacture. See Stefan Marx, 'Advanced T-80 Designs', Jane's Intelligence Review, 7, 9, 1995, pp. 397-400; and Delovaya sibir', 1996 1, p. 10.

${ }^{82}$ Nezavisimoe voennoe obozrenie, 1998,47, p. 6.

${ }^{83}$ Sticking to the criterion of concentrating military orders, support for this centre would exclude the organisations specialised in submarine manufacture situated in Nizhnii Novgorod from the defence industry.

${ }^{84}$ In the building of this class of ship, the association could act as coordinator of the other two military shipyards in St Petersburg, Baltiiskii zavod and Severnaya verf', which would be excluded from the defence industry. See Delovoi mir, 18 November 1997, p. 3. 